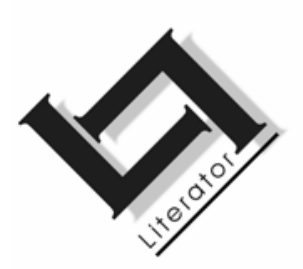

\title{
The mnemonic oral tradition with special reference to the management and expression of conflict in Zulu-speaking communities
}

\author{
N.S. Turner \\ School of IsiZulu Studies \\ University of KwaZulu Natal \\ DURBAN \\ E-mail: turnern@ukzn.ac.za
}

\begin{abstract}
The mnemonic oral tradition with special reference to the management and expression of conflict in Zulu-speaking communities
\end{abstract}

The identification of features of oral studies and especially the issue of conflict and their terms of reference, have recently become a topic of increasing interest among researchers in Southern Africa. The National Research Foundation is nowadays encouraging academics to focus on the area of indigenous knowledge systems. Included in that focus area is the recommendation that research should be done on the impact that indigenous knowledge has on lifestyles and the ways in which societies operate. The study of ways in which specific societies articulate issues of conflict is inextricably linked with the way in which language is used in particular communities. This study deals with African and specifically Zulu communities, and how the mnemonic oral tradition plays an essential role in the oral strategies used as a means of dealing with issues of conflict. These strategies are based on an age-old mnemonic oral tradition which is socialised and used as an acceptable norm of group behaviour. Furthermore it is an acceptable way of managing and expressing conflict in social situations where direct verbal confrontation is frowned upon and deemed unacceptable. 


\section{Opsomming}

\section{Die mnemoniese orale tradisie met spesifieke verwysing na die bestuur en uitdrukking van konflik in Zulu-sprekende gemeenskappe}

Die identifisering van die kenmerke van orale studies en veral die kwessie van konflik en sodanige verwysingsterme, is deesdae 'n onderwerp wat al hoe meer aandag onder navorsers in Suidelike Afrika geniet. Die Nasionale Navorsingstigting moedig tans akademici aan om te fokus op die area van inheemse kennissisteme. Hierby ingesluit is die aanbeveling dat navorsing gedoen moet word oor die impak van inheemse kennis op die leefstyle en maniere waarop samelewings funksioneer. Die studie van maniere waarop spesifieke samelewings konflikkwessies artikuleer, is onlosmaakbaar verbind met die manier waarop taal in spesifieke gemeenskappe gebruik word. Hierdie studie kyk veral na Zulu gemeenskappe en hoe die mnemoniese orale tradisie 'n belangrike rol speel in die orale strategieë wat gebruik word om konflik te hanteer. Hierdie strategieë is 'n aanvaarbare manier om konflik in sosiale situasies te bestuur en uit te druk waar direkte konfrontasie onaanvaarbaar is. Dit is gebaseer op 'n eeue oue mnemoniese orale tradisie wat gesosialiseer is en as 'n aanvaarbare norm van groepsgedrag gebruik word.

\section{General introduction}

The history of Southern Africa over the past three decades and the prevalence of conflict and violence in the political arena as well as the social sphere during this time, makes this study on the features and functions of various speech forms and expressions particularly pertinent, as it serves to throw an important light on the way in which Zulu-speaking communities articulate conflict.

The identification of features of oral studies, and especially the issue of conflict and their terms of reference, have become recently a topic of increasing interest among researchers in Southern Africa. The National Research Foundation is nowadays encouraging academics to focus on the area of indigenous knowledge systems. Included in that focus area is the recommendation that research should be done on the impact that indigenous knowledge has on lifestyles and the ways in which societies are run. The study of ways in which specific societies articulate issues of conflict has a direct bearing on the understanding of the broader field of conflict. The oral expressions that provide the vehicle for venting dissatisfaction in a way that is socially acceptable, are of particular interest as they form an in- 
tricate part of the oral tradition of the Zulu people. These are commonly used in rural communities, but they also still find an echo in urban social settings. Hostility and ill-feelings are thus channelled through the sanctioned form of these various oral expressions either as a means of merely airing one's dissatisfaction or as a means of seeking personal redress. Matters leading to conflict which are dealt with, still in current times, through oral forms (such as praise poetry, the lyrics of songs and naming techniques), include issues such as power struggles, matters of inheritance, ideological differences as well as religious and social differences. Trade union poetry, poetry recited at political gatherings and the poetry composed and recited by workers in work situations such as on the mines, thrived in the stressful political climate of the 1980s and early 1990s. Kromberg (1994:61) explains this phenomenon as resulting from the audience's intimacy with this form of popular oral poetry. Poetry dedicated to trade unions and political parties has been documented in Black Mamba Rising and an extract is cited on page 27 of the praise poetry of FOSATU (Federation of South African Trade Unions) as an example. Kromberg, in his research on worker izibongo, explains the fact that many worker poets acknowledge that they consciously draw on izibongo which represent a tradition with which they and the audience are familiar with and feel an affinity towards. He quotes the words of one of these poets who uses this approach to worker poetry:
we ... join the past to the present and to the future. Our poetry in the traditional form was done in the imbongi style. And once the person stood there and paced the stage, raised his voice, lowered his voice, screeched, pounded the air, immediately people recognised it - hey, this is poetry, let us listen! (Krom- berg, 1994:67.)

Communities use these various oral forms as an acceptable way to manage and ameliorate conflict, and these forms are based very significantly on an age-old mnemonic oral tradition which is socialised and accepted as a norm of group behaviour. This way of viewing conflict and its articulation as events in the comprehensive continuum of social life, is common in Africa. This is because of the community-based style of living prevalent among Africans. Social life in communal societies is the area in which values and norms function, and is the environment in which cultural traditions are formed and handed down in a predominantly oral fashion, from one generation to another. In societies such as this, where the oral mode of transmission is favoured, inter-personal communication on a daily basis characterises social discourse and interaction. It is in this 
environment of constant human communication and interaction that the energy comes which may fuel conflict.

This is in stark contrast to many contemporary literate urban societies in which values, norms and cultural traditions may be communicated more commonly in the written form through the media or through books, in memos, letters, notices and e-mails. This scribal mode of communication tends to alleviate and even prevent conversation and extended oral communication. Literate societies tend to focus on individualism and an individualistic style of life, whereas in societies which are "orally-based" and communal in lifestyle, the important element functioning throughout social life is the network of extended human relations. Family ties and community networking are constantly respected, maintained and strengthened. Whenever kinship or social relationships are disturbed by a dispute, priority is given to restoring the balance. Jannie Malan (1997:24) makes a point about African communities:

The social context can make an important difference if the purpose of the conflict resolution process is formulated in social, relational language. Relationships that have been broken or damaged should be repaired. Wrongs should be rectified and justice restored. The whole procedure of resolving the conflict will also be regarded to be what it actually is: an event in the continuum of social life.

\section{The expression of conflict in Zulu oral compositions}

The izihasho recorded as data originally for this research had not previously been recorded in writing. I have chosen to incorporate the data and their explanatory biographical notes within the main body of the discussion, instead of listing them separately as annotations or notes. I have done this because the evidence which the data supplies gives relevance to the theory. In doing so, I strongly support Barber's recommendation for future work on African oral genres. She suggests that in interpreting oral texts, understanding what the text is composed for, and how the people among whom it operates, understand it, one should incorporate the expositions into the main discussion of the texts and take such analyses out of the footnotes. Her reasoning for this is not

... to instate them as the sole authoritative interpreters, relied on to disclose the 'real' meaning of esoteric texts, but rather to gain access to the available modes and manners in which interpretation is conventionally carried out in that circuit of cultural production. Such investigations ... should help to shed light on 
how meaning is held to be related to text in specific genres and scenes of cultural production. (Barber, 1999:45.)

In most polygamous societies, particularly in Zulu traditional rural societies where women live together in close proximity in the homestead situation, tensions tend to arise. Magwaza (2001:25) makes the point that in addition to this, women in such a patriarchal setting are given "minimal or marginal opportunity to air their views". In line with this, Jafta (1978) and Ntshinga (1993) state that the very nature of Nguni tradition forbids a woman from talking openly about her marriage situation and its inherent problems. Magwaza (2001:27) supports this view:

Zulu women are viewed as custodians of culture who have a duty to transmit ethnic identity to the young. 'Guarding the culture' is held as an important responsibility. In instances where the very culture that is guarded is to the detriment of women's dignity, respect and rights, she is not allowed by tradition 'to answer a man back'.

Tension and rivalries that exist in the close-knit structure of the Zulu polygamous unit find their legitimate outlet as complaints and accusations in izihasho ${ }^{1}$ through allusive diction as in the example cited below, which were recited by this woman's neighbour. His feelings about the subject, MaKhuzwayo, are quite evident here. She is a woman who is not originally from this particular area, but within a short lapse of time after moving in, she knew everything about everybody. When ostracised by certain people who tried to keep information out of her hearing, she went up and down the streets, asking endless questions, in order not to miss out on anything. She

1 The most basic type of izibongo commonly referred to by the English term praise poetry, is simply a collection of extended names. This type of oral expression is used by the common man who, although his izibongo may contain references to events and efforts of endeavour, has not yet been elevated to a position of political importance. This type of izibongo I prefer to refer to as izihasho. Being known by one's izibongo/izihasho provides the person with a distinct identity, a sort of recognition and support which is important to his/her ego and psyche. For this very reason izibongo remains a popular and often necessary form of public expression. I would like to add that in addition to "living up to", one can also witness in the izihasho researched in this article, that one may be exhorted to be wary of "living up to" the more negative aspects expressed in censorious tones. In view of the difficulty encountered when singing these terms in the English translation, I have chosen rather to use them in their Zulu forms and trust the explanations given to describe these terms give a better sense of what they represent in their totality. 
was married but had no children. Her husband eventually left her because of his unhappiness with her behaviour.

The composer has used some humorous images in this oral record, comparing MaKhuzwayo to a dog, emphasising her ability to sniff out spicy information. Due to the fact that she is constantly gossiping, her mouth is described as being constantly sideways, typical of a person who is always whispering secrets.

\section{Izihasho zikaMAKHUZWAYO}

UPhoshozwayo,

Uyazithanda izindaba zabantu.

Akadlulwa ndaba,

Umadlebe afinyelela kuzo zonke izinkalo.

Inja yomoya,

Izizwa ngekhala izindaba,

Kuthi lapho ingezwa,

Itshikizise umsidlana wayo, ikhonkothe.

Umapheka ibhodwe lize lishe,

Ngoba elibele ukulevuza izindaba.

Useze wamlomo ubhek' ecaleni.

Ukudla akasakwazi emlonyeni.

Udlana nezindaba.

Umaxosha umyeni kusale yena.

Impela, ukhanda limtshel' okwakhe.

The Talkative One!

She likes other peoples' stories,

She does not miss a single yarn,

Ears that reach out to every plateau,

Spying dog,

It smells out stories with its nose,

But when it does not hear,

It wags its small tail and barks.

One who keeps the pot on the fire until it burns

Because she is busy talking incessantly,

Her mouth now faces sideways.

She who eats no food,

She devours only stories.

One who drives away her husband and remains behind, Indeed, she is pig-headed! (Turner, 1990:112.)

In researching oral strategies used by Zulu speakers as a means of conflict articulation, one must view these social conflicts as contextualised events in their specific social setting. This entails taking 
into account not only the cultural setting, but also the social discourse, the context and a review of events leading up to and surrounding the conflict situation. In some instances this involves more than just the disputing party, it involves the entire social network in which the conflict is situated. This is evident in the following example of a Maskandi song composed by the well-known Maskandi musician, Shiyani Ngcobo. Maskandi music has become a very popular mode in the last fifteen years of expressing discontent with a variety of contemporary social and political issues. It is a type of neo-traditional instrumental music popular among the Zulu people, which is played on Western instruments such as the guitar, concertina, violin, piano accordion or even electric guitars and drums. Maskandi musicians believe they have an important role to play in society by reflecting on things both positive and negative in the community around them. Most often the lyrics of the song are appreciated because the theme reflects "traditional" Zulu values and beliefs. In this song he expresses his concern with the people who live in his area and their uncompromising support of the Shembite religion. The lyrics of the song express the difficulty he as a Zulu person has, in accepting it as being the religion for all Zulu people. $\mathrm{He}$ accuses the Shembites of being discriminatory, because they propagate Shembe as their religious icon, rejecting the figure of Jesus Christ as the God for foreigners. He also criticises the fact that the Shembites are argumentative and divisive in that they reject all Zulu people who do not follow their religion. In the middle of the song, Ngcobo recites his own izibongo which contain cryptic allusions and aspects of criticism in his own life history. The song is full of mnemonic devices such as parallelism, linking, assonance and alliteration which is typical of the oral mode of expression.

\section{Ukholo Iwakwashembe}

Wo! Khuzani kuyonakala,

Ukholo IwakwaShembe alulungile

Alulunganga nje.

Wo! Khuzani kuyonakala

Ukholo IwakwaShembe alulungile

Luyabandlulula madoda

Ngoba luthi uJesu uyinkosi

yaphesheya

Thina mabhinca sikholwe kanjani na?

Uma nithi uJesu uyinkosi

yaphesheya?

Thina mabhinca sikholwe kanjani no?

Wo! Khuzani kuyonakala,
Be wary of this - things are getting out of hand!

Shembe's religion is not good

Its not good.

It discriminates, men,

Because it says Jesus is Lord from overseas

What should we heathens believe?

When you say Jesus is the Lord from overseas

What must we heathens believe? 
Ukholo IwakwaShembe alulungile luyabandlulula,

Wo! Khuzani kuyonakala, ukholo IwakwaShembe, maZulu luyabandlulula.

Wo! Khuzani kuyonakala,

Ukholo IwakwaShembe, maZulu luyabandlulula nje,

Ngoba luthi uJesu uyinkosi yaphesheya

Thina mabhinca sikholwe kanjani na? People are quarreling on the trains. Abantu sebexabene ezitimeleni oh.

Ukholo IwakwaShembe alulungile, alulunganga,

Luxabanisa abantu

It makes people fight

Ukholo IwakwaShembe alulungile alulunganga,

Luxabanisa abantu.

Repeat of verses 1 and 2

Repeat of verse 3

\section{(Praises)}

Khuluma nazo, Shiyani bathakathi!

Nabulala naqeda umsebenzi, madoda.

Ngosuku olulodwa, uyosebenzani

kusasa

Speak to them, forget/leave the sorcerers!

Badiliziwe abantu bagcwele imigwaqo,

Emsebenzini nakhu bayawuphanga

Umsebenzi, madoda musani ukuwuphanga

Umsebenzi ngosuku olulodwa nje.

Retrenched people are crowding the streets

Because they hurriedly finish their work

Don't, rush the work men,

Don't destroy the work in one day.

Kwasho uSiklebhe indoda, engizalayo kanjalo,

Ubaba lo engikhuluma ngaye, madoda

Khona eMthwalume la ngibuye khona

So said Siklebhe, my father

I'm talking about my father men.

From Mthwalume where I come from 
Umfula engiwuphuzayo phezulu enhla nawo

Wakhuluma nazo ngempela umthakathi wentombi

Engayithumela ngezizwe

Engazinikwa abasenyangeni ngangayizeka

Bangihlawulisa ngibathengile

Indumandumane phela edume ngothando emantombazaneni.

Nithini madoda? Nizwa kanjani makukhulunywa kanjalo manje? Musani ukusibandlulula nina madoda!
I drink from this river's fountain

Talk to them, about who has bewitched a girl

Because I bewitched the maiden with hysteria with muthi

Which I was given by the inyangas, but I did not marry her

They punished me although I paid them

The one who is famous because of his love exploits among the young maidens.

What do you say men about this?

Don't discriminate against us, you men!

In the examples of the Zulu oral texts which I have recorded over a period of fifteen years between 1990 and 2005, the subjects of the oral compositions live in both rural settlements and in urban townships. They are taken to task for social conflict that has arisen because of, among other things, dishonesty, gossip mongering, excessive drinking, irresponsible squandering of income, laziness, hypocrisy and sexual promiscuity.

\section{Oral text in context}

Malinowski's claim that there is "no text without context", is undeniable. The oral texts require a responsive audience, with the performer acting as the leader. This audience is attuned to the performer because they share the same collective memories and culture, and they are therefore able to decode the messages contained in the texts because of this common history. This is clear in the example quoted above of izihasho, women's songs and the lyrics of the Maskandi musician. Performers and composers of these recorded forms are ordinary people. In some instances, certain lines or phrases are composed by peers, sometimes they are selfcomposed. Some of the language contained in many of the texts is regarded as coarse and unsavoury by people from both within and outside the tradition. Such language, however, is acceptable within the specific constraints and context of the actual performance. In articulating dissatisfaction with the promiscuity of a particular nurse who is responsible for treating AIDS patients, the following izihasho reflect this necessity for contextuality as well as exemplifying how 
rough language not entertained in everyday speech finds acceptability in context:

\section{Izihasho zikaNESI waseKING EDWARD}

Umagwaz' ePhoyinti osinqasibomvu, Umubi wengulube!

Ngokuthath' ukiss uwufak' odakeni.

Ungan' ayinacala indab' isocansini.

Umelaph' wengculazi kanti uyayifafaza!

Udilozi liyaxega malibon' indoda.

Into kaThixo ayipheli!

The one who stabs at Point Road with red buttocks,

You are as ugly as a pig!

For taking a kiss and dipping it into the mud.

The child is innocent, the problem lies with the mat.

The healer of AIDS while she spreads it!

The panties are loosened when seeing a man.

This thing of God does not spoil! (Turner, 1990:117.)

These highly metaphoric words would be recited by the peers of this nurse when chiding or teasing her. They would normally be treated with hoots of laughter by those listening, and would cause embarrassment to the recipient on some occasions, depending on who was in the company. It alludes to her abode in Point Road in Durban, notorious as a place of prostitution. The second line refers to her facial appearance, as she is not an attractive woman and the fact that she is not choosy about the appearance or status of her lovers either. The third line seems to reflect the sentiment of debasing sexuality and sexual relations with its metaphor of mud. The fourth line is a jibe at her habit of never sleeping alone. The next line is true irony, she is a nurse whose profession is to render help in curing people, but because of her loose morals, she is actually responsible for spreading disease. The penultimate line speaks for itself, but came into her izihasho for her reported affair with a patient at the hospital. The last line is a line that the woman herself was fond of saying when questioned about her insatiable sexual appetite, implying that no matter how much she engages in intercourse, her sexual organs were indefatigable!

Reference to the written form of text as I have used it in the ambit of this article means a stream of thought, initially orally conceived and expressed, is then recorded in writing. This should, however, not be regarded as a final fixed form once recorded, but remains fluid and 
flexible with each actual oral rendition. The example quoted above would be recited differently depending on where the person was and in front of whom the composition was being delivered. Barber (2005:267) quotes the term "entextualization" which renders a detachable stretch of discourse more shareable and transmittable. Entextualisation then is an attempt to render discourse object-like.

Text must be treated as the object of attention - by exegesis and by being quoted in new contexts of utterance - in order to attain meaning. (Barber, 2005:276.)

The oral texts quoted in all the examples above illustrate the oral form of communication with all its mnemonic built-in strategies, which is still favoured and employed commonly in current situations, "in order to attain meaning", in a world permeated by various forms of scribal communication.

\section{Oral expression and memory}

Oral practices form part of the heritage of the African cultural wealth in its various forms and expressions and they live on, irrespective of whether they are recorded in writing or not. They continue in a parallel fashion to written records, often intermingling with them. Oral practice is the "style" in which the composition is delivered which gives us the vital clue as to what kind of society the text emanates from, i.e. one that favours the oral mode over the written. In such societies the memory is of paramount importance and must be "practised", hence the reliance on what Jousse (1990; 2000; 2001) described as the mnemonic oral style. Jousse identifies the anthropological global oral style. He referred to it as the oral style to describe the use of the gestual-oral medium which comprises audible (chanting, singing and reciting) and visible movement, as a mnemonic (memory enhancing) form of record keeping. This oralgestual medium is the way in which oral societies record their sociocultural affairs. In his exposition of the oral style, Jousse (1990) distinguishes between the oral tradition and the oral-style tradition, in that the oral tradition is the socio-cultural archive that has been passed down from generation to generation not in scribal writing. Both the oral tradition and the oral-style tradition are responsible for the passing down of the socio-cultural archive, the difference is that the oral tradition constitutes knowledge recorded and transmitted while the oral-style tradition is the tradition, way or manner of mnemonic recitation. 
In contemporary society with the influence of literacy and the increasing attendance at schools of young children, there is continuous interplay between the oral and the written. These children, particularly in rural areas with an elementary grasp of reading and writing, live in constant close contact with large numbers of people who are still illiterate or barely literate, (still in the millions in South Africa), and who are heavily reliant on the oral mode of communication. These oral forms of communication thus still find common exposure in contemporary society. In their use these forms are shifting and allusive, and are constantly being moulded anew in the modern conditions in which they are articulated; they are certainly not static in their current forms or functions.

Jousse identifies that human beings are in constant interaction with each other and the world in which they live and that in so doing man reflects, mirrors or imitates what happens to him and around him. He terms this mimism and he further perceives that this interaction and the process of memory or learning are dynamic, and register idiosyncratically, thus accounting for identity and individuality and allowing creativity as a response to idiosyncratic situations. This creativity is born out of reflection and accounts for the idiosyncratic nature of the oral compositions which are recorded in this article which reflect conflict. Mimism is identified by Jousse as one of the four mnemonic laws of the anthropology of geste and rhythm (the others being bilateralism, rhythmism and formulism). As mimism interacts with these other mnemonic principles, it is the process whereby the anthropos "mirrors, voluntarily and involuntarily, the balanced rhythmic formulas of the universe in synchronous balanced rhythmic formulaic expression" (Conolly, 2001). Mimism is the essence of the oral forms which are discussed, which express conflict and social disputes, and which reveal the fact that the Zulu people "express" by means of songs, naming practices and Zulu "praise poetry" (izibongo) what is in-pressed in them - the things that happen around them in their communities. This is reflected in the words of the Zimbabwean musician, Oliver Mtukudzi, who makes the point that "in our culture, we do not sing a song unless there is something to be said" (Sibanda, 2004:37). He continues that he sings about that what he sees around him. These songs commonly deal with issues that reflect his country's socio-political trauma, i.e. bad governance and HIV and AIDS. Specific songs which accompany a distinct form of traditional dance among the Nguni are known as izigiyo songs, and these operate in a similar way to izihasho (praise poetry of the common person) in that they can be used to expose social ills - but the songs have a broader frame of 
reference. They are essentially a communal experience with one person singing the opening line and the others around replying with the chorus lines. Songs are less personal than izihasho in that they are not necessarily directed at any one specific person, although they may be. When they are sung, the message embedded within the lyrics of these songs may be aimed at a more general audience. The following songs sung by women, echo complaints about the infidelity of spouses and the preferential treatment given to other women, as well as an accusation of witchcraft in the third song.

\section{Song 1}

Eyami, eyami le ndoda!

Oyicela kimi mawuyifuna

Eyami le ndoda, eyami!

Oyicela kimi ngiyayiphekela

Eyami le ndoda, eyami!

He is mine, he is mine this man!

Ask me first if you want him.

He is mine, this man, he is mine!

Ask me first, I am the one who cooks for him.

$\mathrm{He}$ is mine this man, mine!

\section{Song 2}

Makugula mina kuthi kutu!

Uma kugul' umnakwethu

Kuphuma amasheke!

If I am sick, well just too bad!

If the co-lover is sick

Out come the cheques!

\section{Song 3}

Ungibheka kanjani?

Iso gunqu iso lomthakathi!

Wangibheka wangeba

Iso gunqu iso lomthakathi!

How are you looking at me?

You look at me with an evil eye, the

eye of a sorcerer!

You look at me with a shifty eye

An evil eye, the eye of a sorcerer! 


\section{Conflict expression in Africa}

This research focuses more specific on Zulu modes of perception and expression of issues involving conflict. However, one must take into account the fact that African societies have evolved traditionally from a non scribally-literate world in which the oral culture projects the sum total of values, beliefs and institutions that have been shared by countless generations. Bozeman (1976:65) suggests that any inquiry into the role of conflict in African politics or society requires a shift of focus to the small folk community: the form of group life that Africans themselves have regarded as enduringly meaningful throughout the centuries. In societies that favour the oral mode of expression over writing, an individual is perceived primarily as an extension or representation of the group to which he belongs, either as a member of a family, clan, lineage, village or other grouping. The Occidental idea of the autonomous person, endowed with individual rights and responsibilities is a very different concept from that of the communal African person. This explains the affirmative African approach to conflict as a socially and psychically vital function. There is a shared perception of conflict as a structuring or constitutive force in communal affairs, where well-regulated adversary confrontations provide fitting circumstances for the blunting of socially threatening tensions. In view of the fragility of social ties between members of various Zulu communities, particularly in periurban and rural settings, actual or potential conflict situations have consistently challenged the traditional genius for maintaining the closely-knit community life. Each Southern African speech community has its own code of customs for abating antagonisms, conciliating disputants and ultimately re-establishing communal accord. There is quite obviously not one single homogeneous Southern African approach to conflict. Nevertheless, when these are surveyed in the perspective of shared cultural patterns, certain common features readily emerge and these are as different from Western (literate) approaches as the situations that provoked them. This is because African systems of conflict control emanate from established social practice and are therefore virtually synonymous with the entirety of social life - they depend primarily upon the medium of oral expression.

\section{Comparative forms of oral communication and conflict in other African countries}

Finnegan (1992:222) mentions the use of oral poetry and song in Africa for the expression and resolution of hostilities between in- 
dividuals or groups in social settings as well as in the political arena. The west Nigerians composed satirical political songs to express their frustrations in the 1959 federal elections, and Bashi singers in the Congo composed songs which were sung in the workplace to express their dissatisfaction and grievances. Finnegan states (1992:223):

... expression in poetry takes the sting out of the communication and removes it from the 'real' social arena. And yet, of course, it does not - for the communication still takes place.

Work songs are common in Africa and are sung by both women and men. Kraemmer (1975:112), in his work among rural folk in northern Zimbabwe, makes the point that work songs

... also provide an occasion when persons would not be called to task for voicing criticism, which frequently took the form of obscene reference in song.

Okpewho (1992:147) in his research on African oral literature, similarly refers to the "critical spirit" in oral forms. He discusses the role of "praise singers" who have license to criticise their rulers with impunity. The role of the imbongi 2 in Southern Africa, as not only the social conscience of the people, but also the voice of the ancestors and the unconscious, has been extensively documented by writers such as Cope (1968), Gunner (1984), Kaschula (1991) and Turner (1990). Okpewho (1992:148) comments that this oral form of personal redress throughout Africa is also common outside ruling circles. He calls these songs of personal abuse lampoons. In Nigeria, the tradition was used by individuals to wage personal vendettas against various members of the community. However, the usefulness of these songs in the oral tradition was to encourage those in society to observe good conduct, while developing a sense of responsibility, and at the same time these lampoons were intended to act as a warning against those in the group who might

The imbongi is a man who not only plays a major role as exalter of the reigning monarch/chief or person of social/political importance, but one who is also the official channel through whom the opinions and general feelings of the populus are reflected back to the recipient of the praises. The imbongi can be seen as a leveler, responsible for lifting his subject's spirits when down by praising him, and bringing him down a peg or two when he flies too high, endeavouring to keep a healthy balance in society. In literate culture the imbongi translates beyond this description into the political analyst or the political activist, in mass media institutions such as labour/union movements or even democratic forms of government. 
be indulging in behaviour that is regarded as detrimental to the wellbeing and general survival of the society. Okpewho (1992:154) also discusses songs and oral compositions as a preferred form of expression in the political arena in Nigeria, Kenya, Zimbabwe and Mozambique. Mapanje and White (1983) document various forms of conflict and protest in the oral expressions of Africa from Mozambique, Sudan, Ghana, Uganda, Zambia, Somalia and Nigeria. In their anthology, there is a specific chapter on poems which reflect aspects of protest and satire. Mapanje and White (1983:129) argue that African oral composers are allowed an unusual freedom of speech:

Sons may criticise their fathers, wives their husbands, workers their employers, and everybody the chiefs or officials who rule them, so long as it is done through poetry or song.

Vail and White (1991) also offer numerous examples of the expression of complaint in song and in oral composition in Africa. They cite examples of the work of Evans-Pritchard (1948) and his collection of work songs among the Dinka; Hugh Tracey's (1948) recordings of songs among the Chopi; Gluckman (1963) and subsequently Kuper's work (1964) on the Swazi Ncwala (first fruits) songs in the context of political struggle. Add to this Sibanda's research (2004) in Zimbabwe and Mafeje's work in South Africa, among others, on the role of the Xhosa imbongi in the 1990s. Lullabies are also documented by Finnegan (1992) as providing an indirect means of critical expression among the Nyoro of Uganda, the Dogon, the Rundi and the Kamba and by Kunene in the 1970s in South Africa.

Mutembei and Lugalla (2002) argue that in Tanzania oral expression has been used by the Haya community from time immemorial as a pedagogical tool to shape social norms and behaviour. It was used not only to preserve the wisdom of the nation, but in more recent times, to document the dilemma in modern societies facing the scourge of AIDS and AIDS-related problems. These researchers have concentrated on the genre of oral "poetry" from the Kagera region of Tanzania as they state that unless those engaged in the fight against the pandemic, whether they be governmental or nongovernmental bodies, use the language of the communities, their intervention measures against the spread of HIV will be of limited success. They cite a study carried out in Uganda where the emphasis is put on the use of language that is understood and accepted by the local communities: 
Promotion of preventive measures will be most effective if carried out by peer educators who notice and communicate social messages in appropriate language situations. This may be important in campaigns aiming at changing attitudes, behaviours and practices. (Obbo, 1991:84.)

Mutembei and Lugalla go on to say that the most important aspect as to why oral compositions have to be given prominence in education campaigns related to HIV and AIDS, is that it gives women a chance to be heard and to air their complaints and anxieties, a channel not normally open to them in other modes of discourse. In addition, the study of these specialised oral compositions creates a unique understanding of the way people themselves construct reality in relation to the epidemic.

\section{The oral mode in the articulation of social conflict in Southern African society}

Scholars such as Bryant (1929), Samuelson (1929) and Grant (1929) were early recorders of Zulu oral traditions in Southern Africa, followed by Cope, Nyembezi and Gunner who documented extensively, the genre of Zulu izibongo. Opland's well known work, Xhosa oral poetry (1983) is as valuable in the Xhosa domain as the work done among the Zulu. Opland shows the resilience as well as the awareness of change in social and political conditions among the Xhosa. He highlights the role of criticism in these oral compositions by imbongi, of the current ruling chiefs, and their subsequent incarceration and harassment during the apartheid era because of their views on matters such as the so-called independence of the Transkei. These findings are echoed in Kaschula's subsequent research on the transitional role of the Xhosa oral poet in contemporary South African society (Kaschula, 1991) and his comparative work on the imbongi and the West African equivalent, the griot (Kaschula, 1999). He records the role of the Xhosa imbongi as former unfettered social critic and political commentator and comments on the changes that occurred from the late 1960s to the end of the 1990s, which sees the imbongi still playing a role as asocio-political commentator.

In earlier work, he quotes the example of Chief Ndamase (Kaschula, 1991) who regards the imbongi simply as an entertainer. As the imbongi was, and still is, at risk for what he says, we find a total change in the role of the traditional imbongi. He no longer acts as mediator between the chief and his people, someone who may at will extol or criticise with impunity. Urbanisation, economic pressures 
on the individual, the influence of Westernisation, the then highly charged political atmosphere of the apartheid state, the role of the media, formal education and the changing political situation are all documented by Kaschula in the changing conditions which faced the contemporary imbongi (bard).

Gunner (1984) also conducted extensive research in the field of Zulu contemporary oral compositions. She assesses the key role of izibongo in presenting and expressing identity and she outlines the form and content of individuals' izibongo, as well as describing the performed aspects thereof. In her discussion on allusion as a form of criticism she deals with certain aspects that revolve around criticism and conflict. The point that Gunner makes, albeit briefly, is that conflict, when it occurs in men's izibongo is usually only one of a number of briefly explored topics. In women's izibongo, however, Gunner states that criticism and complaint tend to be the dominant themes. She points out that this allusory criticism is also prevalent in the izangelo (izibongo of infancy) which are normally recited in front of audiences comprising women only. In an earlier study Gunner (1984:330) also mentions briefly the theme of conflict in the izibongo of ordinary people, where the content of the izibongo is extremely negative and critical, in this way exerting social pressure and "pulling behaviour back into line".

This topic of social pressure and "pulling-back-into-line behaviour" has also been the focus of previous research by Turner (1990; 1992; $1995 ; 1997 ; 2001 ; 2003)$ in documenting the oral compositions of ordinary Zulu men and women. Here the emphasis in the examples cited is largely on highlighting social behaviour that needs correction.

In their publication Musho (1994), Gunner and Gwala present a collection of oral compositions of national figures, chiefs as well as ordinary men, women and children. In their introduction, the authors describe izibongo as a "key art form in the political discourse of the day" where the izibongo of the kings and national figures was used increasingly in the 1960 s and 1970 s as part of political gatherings. Conflict expression is touched upon briefly in isolated examples. Groenewald's research (1994) among the Ndebele of Southern Africa focused on the use of izibongo for political effect in the izibongo of Prince James Senzangakhona Mahlangu. These analysts, namely Gunner and Gwala, as well as Groenewald reveal how the form of Nguni izibongo has been manipulated by performers and politicians to criticise political ideologies of the day. The izibongo of national figures contain within them criticism of unpopular actions 
that they may have taken as well as the opinions of the people about unpopular situations. In his capacity as representative of not only the community but also of the ancestors, the imbongi (the bard) presents these opinions to figures of authority. Gunner (1994:31) argues that:

The extent to which South African traditional art forms have been stereotyped and under-estimated in their capacity as agents both mirroring and engaging with social and political life, is only now beginning to be explored.

Kromberg (1994) who documents examples of worker izibongo, continues the work done by Gunner, Groenewald, and others and describes the transformation of izibongo from a medium for praising chiefs to a medium for worker mobilisation. This is evidenced in the trade union/worker Zulu izibongo cited below.

\section{Izibongo zikaFOSATU}

Nguye wavela!

Basho bonke bathi wavela!

Wena hlathi elihambayo lase Afrika.

Ngifike amawele elilelana

Kanti ngabasebenzi

Abasebenza ezimbonini

Bexoxelana ngezinkinga

Ezibahlupha ezimbonini

Abazisebenzela eAfrika.

Sikhukhukazi esimaphikw' abanzi

Okufukamel' amatshwele aso

Sifukamel' amatshwele aso

Sifukamele nathi

ngalawamaphiko akho angena ubandlululo

Sikhukumeze nathi

ukuze sihluzele ingqondo sihlakaniphe.

Anolaka amadodana akho

Ingabe uwachela ngaluphi uhlobo Iwentelezi.

Sichele nathi

ukuze siwafuze senze njengawo.

Uzele phela uFOSATU.

Amadodana akhe

agcwele iAfrika yonkana.

Chakijana wogcololo

Mphephethi wezinduku zabafo,

Vuka! Ugqoke amandl' akho okuhlakanipha

Vala amasango akho FOSATU 
Ngoba izitha zabasebenzi ziyakuzungeza

Zifuna intuba

yokungena phakathi kwakho zikuhlakaze,

Oh! siyokuba sifile thina basebenzi

uma bephumelela

Valabo! vala!

Khula nginciphe,ngiyeza kancane!

Ngikubhekile konke okwenzayo!

Ulibinda FOSATU!

Bayethe!

Amandla kubasebenzi. (Qabula et al., 1986:7.)

When I arrived the children were all crying

These were the workers,

Industrial workers

Discussing the problems that affect them in the industries

they work in for Africa.

You are the hen with wide wings

That protects its chickens.

Protect us too with those

Sacred wings of yours

That knoweth no discrimination

Protect us too so that we gain wisdom.

Militant are your sons and daughters

One wonders what kind of muti they use

Sprinkle it on us too so that we take

After them and act likewise.

FOSATU has given birth

Its sons are spread all over Africa.

\section{Trickster}

The one who repels the weapons of the enemies

Wake up and wear your clothes

Of power and wisdom

Keep your gates closed FOSATU

Because the worker's enemies are ambushing you

They are looking for a hole to enter through

In order to disband you

Oh! We poor workers, dead we shall be

If they succeed in so doing

Close! Please close! 
I am coming slowly and I am watching all that you are doing.

You're great FOSATU.

Hail!

Power to the workers!

\section{Conclusion}

Oral forms of combative speech in the form of insult, ridicule, witty, and derisive commentary in a variety of forms of oral composition are recognised in many African societies and many other parts of the world, as effective weapons of social sanction. In a non-literate culture in which the word is the equivalent of the act, talking invites artistry and verbal virtuosity in the form of repetition, and circumlocution is meant to extend rather than to contract the discourse and therewith also, the pleasure of actual and vicarious participation among those present. Roberts (1979:40) quotes research which shows that people in communal African societies are extremely sensitive not only to ridicule but even to the mildest criticism. This influences them strongly to adhere to approved patterns of behaviour. Shame and rejection represent an extremely powerful means through which deviant behaviour can be controlled, and this is particularly prevalent in close-knit rural communities. Roberts (1979:42) maintains the following:

In any small closely knit community where people find themselves in continuing face-to-face relations, the threat of exposure to ridicule and disgust, provoking feelings of shame and remorse, must represent an important mechanism of control ... Almost all these means of maintaining order, particularly those which derive their force from the actor's perception of how other people may react, operate through human communication in the course of everyday life. Through talk, values and norms may be expressly stated, and consequences of departure from them spelled out.

Conflict is treated as an essential part of Zulu social life and this conflict can only be understood within a context of extended social processes dependent largely upon the beliefs that are held and the values subscribed to within a given community. Conflict is thus seen as performing group-maintaining functions insofar as it regulates systems of relationships, i.e. it "clears the air" and helps to create a situation where hostile feelings are allowed free behavioural expression. In this way, conflict can be constructive. The crux of this article, however, is to draw attention to the fact that the strategies for dealing with various forms of conflict, be it in a social, religious or 
political sphere, are still commonly orally situated as a result of the culture among the Zulu (and many other African people). This cultural practise is one that seeks to minimise damage and avoid the unacceptable outright confrontational nature of direct and unambiguous speech, more symptomatic of Western cultures. Barber's article (1999:38) on "Obscurity and exegesis in African oral praise poetry" raises important points on this subject with reference to Yoruba oriki. She (Barber, 1999:33) claims:

Obscurity and its exegesis (or lack of exegesis) are central to what these texts mean ... Their lack of transparency, their detachment from the normal plain of referentiality, the often tortuous tracks required to expound their meaning, heighten the sense of their value.

She goes on to explain that their lack of transparency and their obscurity in one sense, constitute objects by which one can exercise interpretative skills. They are essential, and when the occasion arises, they need to be dense and weighty in order to deliberately disguise messages and meanings of words.

Jousse makes it clear by multiple examples that it is in the nature of memory and performance that the density and the obscurity occurs. The mnemonic oral style is not necessarily about being difficult but about being accurate in transmission of the message over time. However, it is also the measure of wisdom and intellectual capacity. In the oral-style society, the one who knew the most was highly revered.

When the "recorded text" is detached from the performance, it becomes more obscure, because its contextual function no longer animates it and gives it form and significance. By virtue of its mode of expression, the gestual-oral mode is three dimensional, immediate and spontaneous with interaction between performer and audience, and needs to be considered as action/interaction, rather than as a two-dimensional fixed inert text. In his comprehensive book on African oral literature, Okpewho (1992:31) observes that in oral societies:

texts were handed down from person to person and from one generation to the next, the question of individual authorship was considered superfluous. ... Certain texts are deliberately made to abdicate the identity of their composers. 
The interaction between performer and audience often influences the style and outcome of the performance, which ultimately implies that:

Group interactive authorship during performance over an indeterminate period of time - performs social and moral normreferencing and cohesive functions within the relevant group. (Conolly, 2001(1):95.)

Whilst the scribal form, used as the basis of this article, records aspects of the linguistic elements of the performance, it lacks the dynamic vitality of the non-verbal aural features such as pitch, emphasis, non-verbal sounds, as well as features such as movement and gesture, pause and pace and particularly the response of the audience. Also, it lacks the flexibility of context-responsive variations. Nevertheless, the scribal recordings of these mnemonic oral compositions document a vibrant form of social tradition that is mutating in terms of focus and content, but sadly in modern situations, particularly urban ones, as time goes by, it seems to be a tradition that is gradually disappearing.

\section{List of references}

BARBER, K. 1999. Obscurity and exegesis in African oral praise poetry. (In Brown, Duncan, ed. Oral literature and performance in Southern Africa. Cape Town: David Philip. p. 27-49.)

BARBER, K. 2005. Text and performance in Africa. Oral tradition, 20(2):264277.

BOZEMAN, A.B. 1976. Conflict in Africa: concepts and realities. Princeton: Princeton University Press.

BRYANT, A.T. 1929. Olden times in Zululand and Natal. London: Longmans.

CONOLLY, J. 2001. An annotated and glossed English translation of memory, memorisation and memorisers in ancient Galilee by Marcel Jousse: a study of the origin, nature, analysis and recording of mnemonic rhythmostylistic texts. Volume 1-3. Durban: University of KwaZulu Natal. (Ph.D. thesis.)

COPE, A.T. 1968. Izibongo: Zulu praise poems. Oxford: Clarendon.

EVANS-PRITCHARD, E.E. 1948. Nuer modes of address. Uganda journal, 12:166-171.

FINNEGAN, R. 1992. Oral poetry. Cambridge: Cambridge University Press.

GLUCKMAN, M. 1963. Custom and conflict in Africa. Oxford: Blackwell.

GRANT, REV E.W. 1929. Izibongo of the Zulu chiefs. Bantu studies, 3:201-244.

GROENEWALD, H. 1994. In praise of resistance. Unpublished paper presented at SAFOS Conference, Pilansberg.

GUNNER, E. 1984. Ukubonga nezibongo: Zulu praising and praises. London: University of London. School of Oriental \& African Studies. (Ph.D. thesis.)

GUNNER, E. \& GWALA, M. 1994. Musho: Zulu popular praises. East Lansing: Michigan University Press. 
JOUSSE, M. 1990 [1925]. The oral style. Translated by E. Sienaert and R. Whitaker. New York: Garland.

JOUSSE, M. 2000. The anthropology of geste and rhythm. Edited by E. Sienaert and translated in collaboration with J. Conolly. Cape Town: Mantis.

JOUSSE, M. 2001 [1930]. The parallel rhythmic recitatives of the rabbis of Israel. Cape Town: Mantis.

KASCHULA, R.H. 1991a. The transitional role of the Xhosa oral poet in contemporary South African society. Grahamstown: Rhodes University. (Ph.D. thesis.)

KASCHULA, R. 1991b. Some thoughts on the orality-literacy debate, with specific reference to the Xhosa Imbongi. (In Sienaert, E., Bell, N. \& Lewis, M., eds. Oral tradition and innovation. Durban: University of Natal Oral Documentation and Research Centre. Vol. 12:55-76.)

KASCHULA, R. 1999. Imbongi and griot: towards a comparative analysis of oral poetics in Southern and Western Africa. Journal of African cultural studies, 12(1):55-76.

KRAEMMER, J.E. 1975. The dynamics of a changing music system in rural Rhodesia. East Lansing: University of Michigan. (Ph.D. thesis.)

KROMBERG, S. 1994. Worker izibongo and ethnic identities in Durban. Journal of literary studies, 10(1):57-74.

KUPER, H. 1964. The Swazi: a South African kingdom. New York: Holt, Reinhart \& Winston.

MAGWAZA, T. 2001. Private transgressions: the visual voice of Zulu women. Agenda, 29:25-32.

MALAN, J. 1997. Conflict resolution: wisdom from Africa. Durban: Accord.

MAPANJE, J. \& WHITE, L., eds. 1983. Oral poetry from Africa. London: Longman.

MUTEMBEI, A.K. \& LUGALLA, J.L.P. 2002. Using narratives to understand people's experience on AIDS: examples from oral poetry of the Bahaya of Bukoba, Tanzania. Unpublished paper delivered at the Conference on Language, Literature and the Discourse of HIVIAIDS in Africa, hosted at the University of Botswana, Gabarone, June 2002.

OBBO, C. 1991. African women: their struggles for economic independence. London: Zed.

OKPEWHO, I. 1992. African oral literature. Indianapolis: Indiana University Press.

OPLAND, J. 1983. Xhosa oral poetry. Cambridge: Cambridge University Press.

QABULA, A.T., HLATSHWAYO, M.S. \& MALANGE, N. 1986. Black mamba rising. Durban: Culture \& Working Life Publications.

ROBERTS, S. 1979. Order and dispute. New York: Penguin.

SAMUELSON, R.C.A. 1929. Long, long ago. Durban: Knox.

SIBANDA, S. 2004. You don't get to sing a song when you have nothing to say: Oliver Mtukudzi's music as a vehicle for socio-political commentary. Social dynamics, 30(2):36-63.

TRACEY, H.T. 1948. Chopi musicians: their music, poetry, and instruments. London: Oxford University Press.

TURNER, N.S. 1990. Elements of satire in Zulu oral traditions. Durban: University of KwaZulu Natal. (M.A. dissertation.) 
TURNER, N.S. 1992. Zulu names as echoes of censure, discontent and disapproval within the domestic environment. Nomina Africana, 6(2):4256.

TURNER, N.S. 1995. Censure and social comment in the Izihasho of urban Zulu women. Alternations, 2(2):55-73.

TURNER, N.S. 1997. Onomastic caricatures: names given to employers and co-workers by Black employees. Nomina Africana, 11(1):50-66.

TURNER, N.S. 2001. Humorous names: verbal weapons. South African journal of African languages, 21(4):449-458.

TURNER, N.S. 2003. Oral strategies for conflict expression and articulation of criticism in Zulu social discourse. Durban: University of KwaZulu Natal. (Ph. D. thesis.)

VAIL, L. \& WHITE, L. 1991. Power and the praise poem. Charlottesville: University Press of Virginia.

\section{Key concepts:}

conflict articulation

mnemonic oral tradition

Zulu oral strategies

\section{Kernbegrippe:}

konflikartikulasie

mnemoniese orale tradisie

Zulu orale strategieë 
